Article

\title{
European Snow Cover Characteristics between 2000 and 2011 Derived from Improved MODIS Daily Snow Cover Products
}

\author{
Andreas J. Dietz *, Christoph Wohner and Claudia Kuenzer \\ Earth Observation Center (EOC), German Remote Sensing Data Center (DFD), German Aerospace \\ Center (DLR), Oberpfaffenhofen, D-82234 Wessling, Germany; \\ E-Mails: Christoph.Wohner@dlr.de (C.W.); Claudia.Kuenzer@dlr.de (C.K.) \\ * Author to whom correspondence should be addressed; E-Mail: Andreas.Dietz@dlr.de; \\ Tel.: +49-08153-28-1511; Fax: +49-08153-28-1458.
}

Received: 30 June 2012; in revised form: 7 August 2012 / Accepted: 9 August 2012 /

Published: 15 August 2012

\begin{abstract}
Mean snow cover duration was derived for the entire continent of Europe based on the MODIS daily snow cover products MOD10A1 and MYD10A1 for the period from 2000 to 2011. Dates of snow cover start and snow cover melt were also estimated. Polar darkness north of $\sim 62^{\circ} \mathrm{N}$ and extensive cloud coverage affected the daily snow cover, preventing a direct derivation of the desired parameters. Combining sensor data from both MODIS platforms and applying a temporal cloud filter, cloud coverage and polar darkness were removed from the input data and accuracy remained above $90 \%$ for $87 \%$ of the area. The typical snow cover characteristics of the whole continent are illustrated and constitute a unique dataset with respect to spatial and temporal resolution. Abnormal events, glacier inventories or studies on possible impacts of climate change on snow cover characteristics are only some examples for applications where the presented results may be utilized.
\end{abstract}

Keywords: snow cover duration; MODIS snow products; European snow cover; snow cover start (SCS); snow cover melt (SCM); snow cover beneath clouds

\section{Introduction}

Snow cover is an important variable for water availability [1], it influences the radiation budget of the Earth surface [2,3], and may cause natural disasters such as avalanches or floods after the melting process $[4,5]$. Within Europe especially in Norway, Sweden, and Switzerland, snow is an important 
source of freshwater for reservoirs and the subsequent production of electricity [6-8]. Climate change affects parameters such as snow cover duration (SCD), generally leading to its decrease, a delayed snow cover onset and earlier snow melt [9-12]. Between 1970 and 2004, SCD decreased for most of Northern and Eastern Europe [13,14] and is projected to decrease in the future [15]. Lower elevations are more vulnerable to a reduced SCD than mountainous terrain [16]. Possible changes also include fewer frost days, reduced snow depth, reduced snow water equivalent, changes in soil frost and snow-fed river systems [15,17-19]. The analysis of remotely sensed data allows for high temporal and high areal coverage of the land surface, therefore forming an ideal tool to observe status and dynamics of snow coverage [20].

The aim of this study is to generate a medium resolution snow cover inventory of Europe, including SCD as well as information about snow cover start (SCS) and snow cover melt (SCM). These parameters can provide information about the current status of snow cover characteristics on a continental scale and are a useful source for future climate change studies. Additionally, the results from single snow cover seasons can be used to identify areas with exceptionally long or short SCD and early or late SCS and SCM. Such abnormal events can have severe impacts on economy or the environment.

This study will fill a gap in currently available snow cover products, since they are available either in very coarse resolution ( $25 \mathrm{~km}$ or less) on a hemispherical scale $[14,21]$ or in medium resolution ( $\sim 500 \mathrm{~m})$ only for single countries such as, e.g., Switzerland [22], Poland [23], or Norway [24]. The continental snow cover inventory presented here is the first medium resolution product for Europe that spans the full operational phase of MODIS (since 2000). Our datasets contribute to the satellite-based climate products as stated by GCOS concerning horizontal $(1 \mathrm{~km})$ and temporal (daily) resolution [25]. The extent of the included landmass covers nearly 6.3 million $\mathrm{km}^{2}$.

\section{Base Data and Study Region}

\subsection{Satellite Data}

We used the daily snow cover products MOD10A1 (from Terra MODIS, available since March 2000) and MYD10A1 (from Aqua MODIS, available since July 2002) derived from the Moderate Resolution Imaging Spectroradiometer (MODIS) to calculate snow cover parameters including SCD, SCS and SCM for Europe. The MODIS product is provided by the National Snow and Ice Data Center (NSIDC) and available for the whole globe. The spatial resolution is $500 \mathrm{~m}$ per pixel. Based on the Snowmap algorithm developed especially for MODIS [26], the accuracy of the daily snow cover data reaches $93 \%$ under clear sky conditions [27] as it was confirmed by several independent studies [28-33]. The Snowmap algorithm relies on MODIS bands $4(0.545-0.565 \mu \mathrm{m})$ and $6(1.628-1.652 \mu \mathrm{m})$ to calculate the Normalized Difference Snow Index (NDSI), which is most useful for detecting snow covered areas [34]. Since band 6 is non-functional on Aqua MODIS, band $7(2.015-2.155 \mu \mathrm{m})$ is utilized to derive the snow cover product MYD10A1 [35]. We acquired and processed more than 102,000 single tiles of MOD10A1 [36] and MYD10A1 [37] for the years from 2000 to 2011 from the metadata and service discovery tool Reverb [38]. Though the data is available on a daily basis some days are missing from the time series (Table 1). The methods section will outline how we dealt with these missing observations. 
Table 1. Missing days per year for both MODIS platforms.

\begin{tabular}{lrrrrrr}
\hline Year & $\mathbf{2 0 0 0}$ & $\mathbf{2 0 0 1}$ & $\mathbf{2 0 0 2}$ & $\mathbf{2 0 0 3}$ & $\mathbf{2 0 0 4}$ & $\mathbf{2 0 0 5}$ \\
\hline MOD10A1 & 5 & 12 & 10 & 10 & 1 & 0 \\
MYD10A1 & & & 16 & 1 & 0 & 0 \\
\hline Year & $\mathbf{2 0 0 6}$ & $\mathbf{2 0 0 7}$ & $\mathbf{2 0 0 8}$ & $\mathbf{2 0 0 9}$ & $\mathbf{2 0 1 0}$ & $\mathbf{2 0 1 1}$ \\
\hline MOD10A1 & 1 & 0 & 5 & 2 & 0 & 0 \\
MYD10A1 & 0 & 1 & 0 & 0 & 0 & 0 \\
\hline
\end{tabular}

Shuttle Radar Topography Mission (SRTM) data was also used for this study. The elevation information contained in the SRTM data was consulted to compare SCD with topography. Results are provided in Section 4. SRTM data was acquired from the CGIAR-CSI SRTM 90m Database [39].

\subsection{Snow Depth Station Data}

Snow depth information from the European Climate Assessment \& Dataset Project (ECA\&D) was utilized for accuracy assessment of our results [40]. This data originates from meteorological stations and includes mean daily snow depth measurements for the full time series from 2000 to 2011 [41]. 896 snow depth stations from this archive fall within our study area, mostly concentrated on the Netherlands and Norway (Figure 1). Several stations also exist for Germany, Sweden, Switzerland, and Slovenia but there is no snow depth data available, e.g., for France, England, Poland, or Finland. We used the blended version of the daily snow depth data: Gaps in this time series are filled based on nearby stations if they lie within $12.5 \mathrm{~km}$ horizontal and $25 \mathrm{~m}$ vertical distance [41].

\subsection{Study Region}

Figure 1 presents an overview of the study region, the position of processed MODIS tiles, as well as the extent and the intensity of polar darkness.

The climate in Europe is diverse. Norway, Iceland, Finland and large parts of Sweden (north of $\sim 60^{\circ} \mathrm{N}$ ) are characterized by a humid snow climate. In this region, the longest SCD, early SCS and late SCM are expected. In Central Europe, England, Ireland, France, northern Spain, and southeast Europe, warm temperate climate follows with warm summers and again humid conditions. Here, moderate SCD, SCS and SCM are expected. Southern Europe, including Portugal, Spain, South Italy, and most of the Balkan Peninsula (except Bulgaria, Romania and Serbia) is characterized by warm climate and dry summers. The shortest SCD is expected here due to limited precipitation [42]. The high mountain ranges of the Alps, Carpathian Mountains, and the Pyrenees are excluded from these large scale climate zones. They are characterized by a regional climate influenced by topography, higher precipitation rates and lower temperatures.

Polar darkness affects areas north of $\sim 62^{\circ} \mathrm{N}$, although true polar night where the sun does not rise above the horizon for the full day is only present north of the Polar Circle (66 $\left.33^{\prime} 44^{\prime \prime} \mathrm{N}\right)$. Since MODIS is an optical sensor, valid observations of the Earth's surface are only possible during daylight. The duration of polar darkness is included in Figure 1 . At $\sim 62^{\circ} \mathrm{N}$, only one day is missing from the time series of daily snow cover data due to the influence of polar night. This duration increases to 71 days directly at the Polar Circle, increasing further to 104 days in the most northern regions of Norway. 
Figure 1. Study region, MODIS coverage, extent, station locations, and intensity of polar darkness.

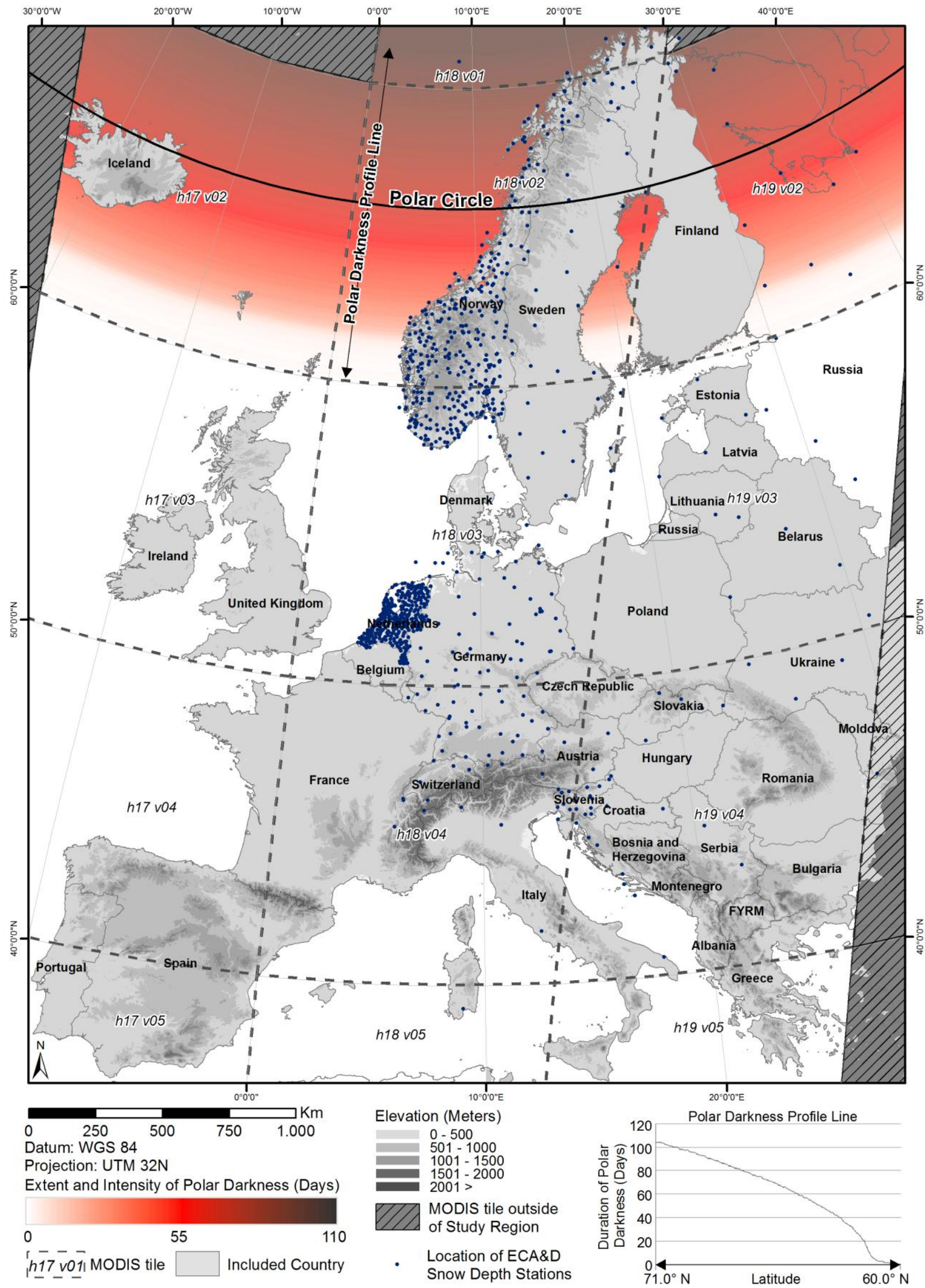




\section{Methods}

\subsection{Estimation of Snow Cover Status below Clouds and during Polar Darkness}

Mean cloud cover percentage for Europe was $46.86 \%$ for Terra and $48.47 \%$ for Aqua MODIS observations. Figure 2 gives an overview of the mean cloud cover distribution for each Terra MODIS tile over Europe between 2000 and 2011 (dashed plots: five-day cloud cover percentage, straight plots: mean monthly cloud cover percentage; dotted plots: polar darkness (only Figure 2(A)). Only cloud covered land surfaces are incorporated in figure 2 while oceans are excluded. The most northern tile row $\left(60^{\circ} \mathrm{N}-70^{\circ} \mathrm{N}\right.$; Figure $\left.2(\mathrm{~A})\right)$ is characterized by continuous cloud cover throughout the year that is only interrupted by polar darkness between November and January. Between $40^{\circ} \mathrm{N}$ and $60^{\circ} \mathrm{N}$, cloud coverage is higher during the cold seasons (Figure 2(B,C)) except for h17v03 that has its maximum during summer months (UK/Ireland tile, Figure 2(B)). Lowest cloud coverage is found south of $40^{\circ} \mathrm{N}$ and within summer months (Figure 2(D)).

Figure 2. Mean cloud cover distribution in Terra MODIS daily snow cover product MOD10A1.

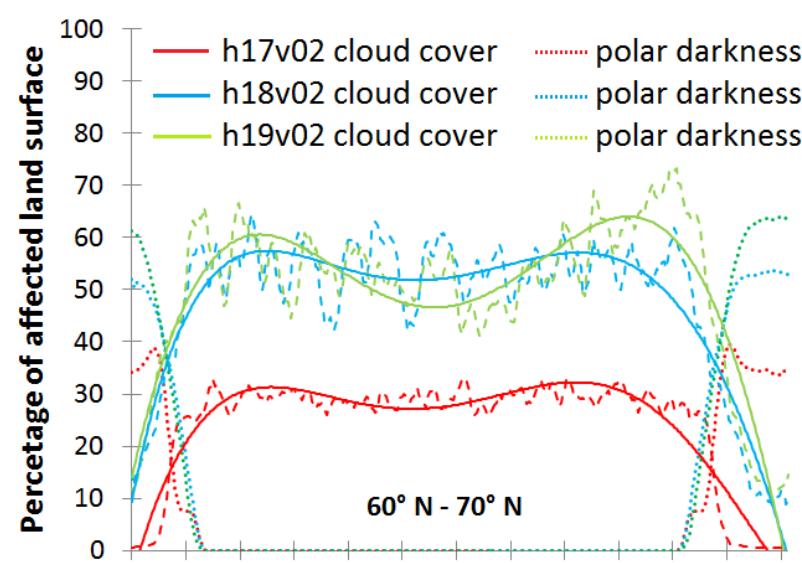

A) 1316191121151181211241271301331361 Calendar day (January 1st - December 31st)

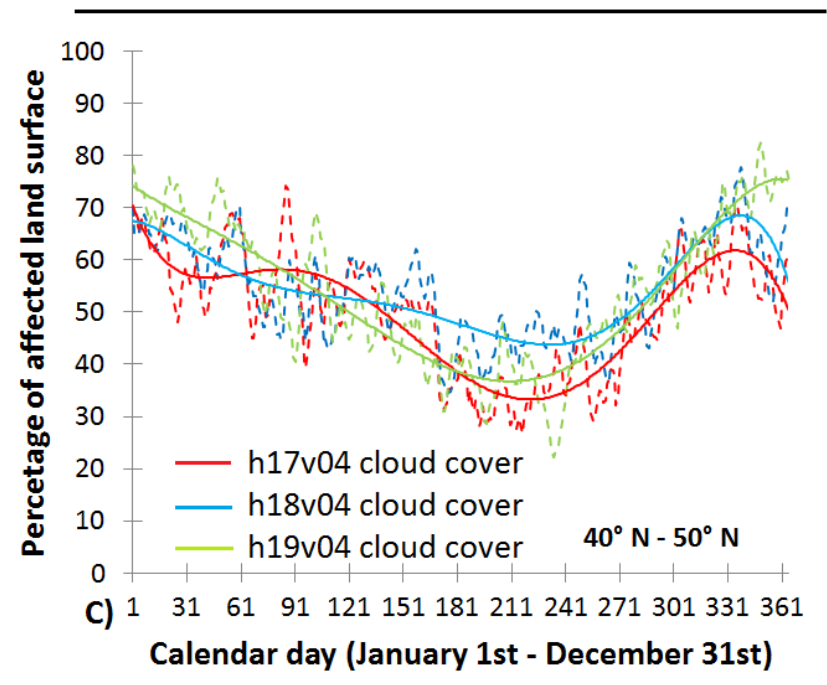

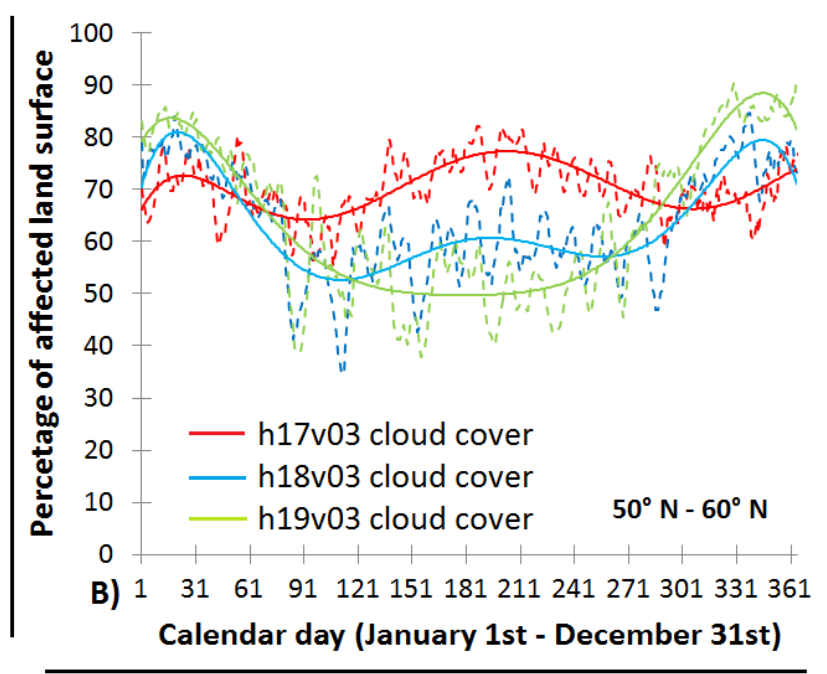
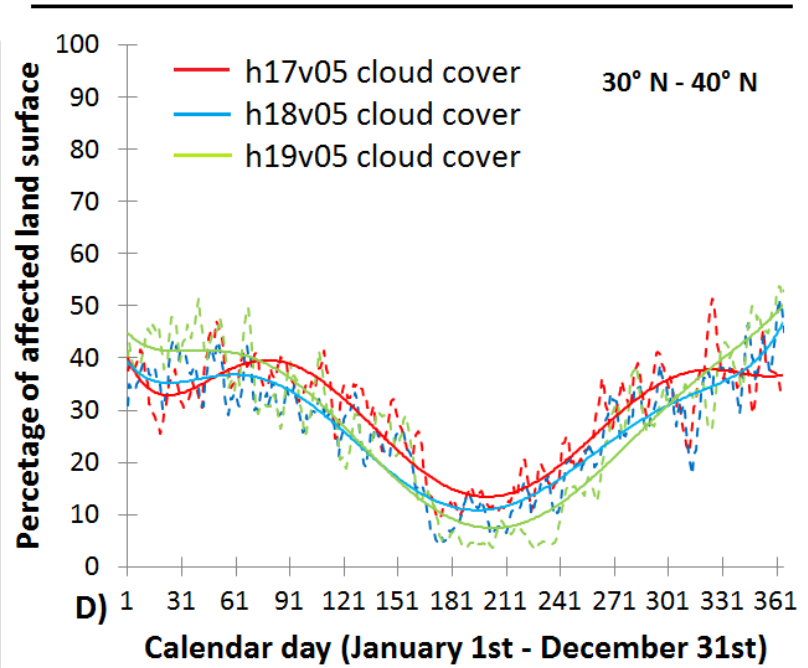

To calculate SCD, SCS, and SCM, snow cover status below clouds and during darkness must be estimated. We applied two different techniques: In the first step, snow cover information from both products-MOD10A1 and MYD10A1-were combined. The difference in observation time between 
the Terra and Aqua platforms (local equatorial crossing time of Terra: 10:30 a.m. in a descending node; Aqua: 1:30 p.m. in an ascending node) leads to changed cloud cover distribution. By applying this step, cloud coverage was reduced to $39.9 \%$. This method was already used in various studies [43-45] but could only be applied to dates after 4 July 2002 due to the fact that Aqua MODIS was only operational since that time. For days before this date, only MOD10A1 from Terra MODIS was available and transferred to the second step without any processing.

The second step involves a combination of multiple observation dates. We followed a technique already used by [46] and [47]: The starting day of a hydrological year contains only permanent ice, land and lakes. Any scene after this starting day is compared to the previous day and if clouds are present, the values from the previous day are substituted for the cloudy pixels. The accuracy of this step depends on the amount of days used to fill data gaps. In Figure 3, the mean number of days with continuous cloud coverage is depicted after the combination of Terra and Aqua MODIS has been applied. Most cloud cover was cleared within three days of the time series. Pixels affected by polar darkness are not included in this figure. The maximum time span until the first clear-sky observation is available for these pixels depends on the duration of polar darkness and can be reviewed in Figure 1.

Figure 3. Amount of days with continuous cloud cover.

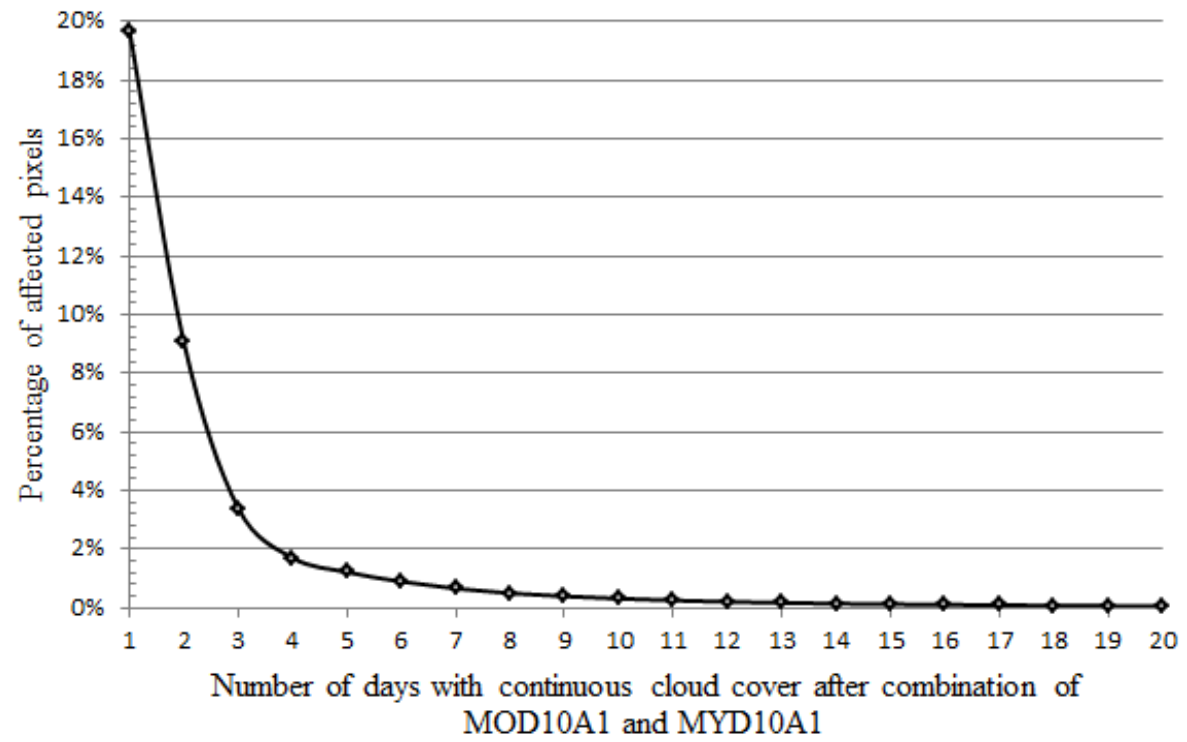

The missing days (Table 1) were substituted with the equivalent product from the concurrent platform: Missing Terra observations with Aqua and vice versa. Before Aqua was operational in July 2002, missing Terra observations could not be replaced and were therefore treated as $100 \%$ cloud covered.

The same approach was used to handle polar darkness in Scandinavia and Iceland: Pixels flagged as darkness were processed by the second step to estimate snow cover status. The temporally nearest cloud-free observation was used as substitution for these pixels.

\subsection{Calculation of SCD, SCS, and SCM}

The cloud-free daily snow cover data were aggregated to form a full time series of hydrological years (1 September through 31 August of the next year) for all years from 2000 to 2011 according to Equation (1): 


$$
S C D=\sum_{i=1}^{n}\left(s_{i}\right)
$$

where $S C D$ stands for snow cover duration, $n$ for the number of days, beginning with 1 September and ending with 31 August of the next year. $s_{i}$ refers to the cloud-free daily snow cover data sets that were recoded to values 1 for snow and 0 for snow-free area. The result is a data set containing values ranging from 0 (no snow at all) to 365/366 (snow covered throughout the year/glaciers).

To derive SCS and SCM for each year, we adopt the method described by [44] but modify the parameters. Equations (2) and (3) explain the procedure:

$$
\begin{aligned}
& S C S=F d-S C D_{b F d} \\
& S C M=F d+S C D_{a F d}
\end{aligned}
$$

$F d$ is a fixed date within the hydrological year and $S C D_{b F d}$ and $S C D_{a F d}$ refer to SCD before the fixed date and the SCD after the fixed date, respectively. $F d$ was chosen to coincide with the maximum snow cover extent throughout all years which is 15 January. The procedure was applied to every year from 2000/2001 to 2010/2011 and results are provided in Section 4. Intermittent snow coverage is disregarded within this method [44].

\subsection{Accuracy Assessment}

We analyzed the data from the ECA\&D snow depth stations to assess the accuracy of our results. The ASCII tables were transferred to a GIS and SCD, SCS and SCM were calculated based on the number of days with snow depth greater than $0 \mathrm{~cm}$ and Equations (1), (2), and (3). A comparison between the snow cover parameters derived from MODIS and those from the station networks allows for an assessment of over- or under-estimation of actual snow coverage. The difference in scale (500 $\mathrm{m}$ raster data compared to point data), different observation times and the uneven distribution of the stations may cause uncertainties in the procedure. The MODIS product will only indicate snow coverage if the pixel is covered by snow for at least $50 \%$ of the pixel [48]. The point data from the station network does not include information about fractional snow cover around the station. However, because the station data is independent from cloud coverage and polar darkness, it forms an appropriate source to assess the accuracy of the generated SCD, SCS and SCM results. The accuracy of clear-sky pixels has already been assessed by various authors as it was denoted in Section 2.1. Station data constitutes the only known data source that is available on a daily basis for most of Europe and independent from cloud coverage and darkness. A similar approach was applied by [1] to assess the accuracy of MODIS-derived snow cover parameters for Liaoning Province, China, with station data.

\section{Results and Discussion}

\subsection{Results of the Accuracy Assessment}

We compared the complete time series of SCD, SCS and SCM with the reprocessed station data. The results are given in Figures 4 and 5. The difference between station-SCD and the MODIS-derived SCD stays below 36 days for $87 \%$ of the investigated pixels. $10 \%$ of the pixels are affected by error 
rates between 37 and 72 days while only $3 \%$ of the area is characterized by more than 72 days deviation between station data and the MODIS SCD result.

Figure 4. Accuracy of snow cover duration according to the comparison with snow cover duration from station data.

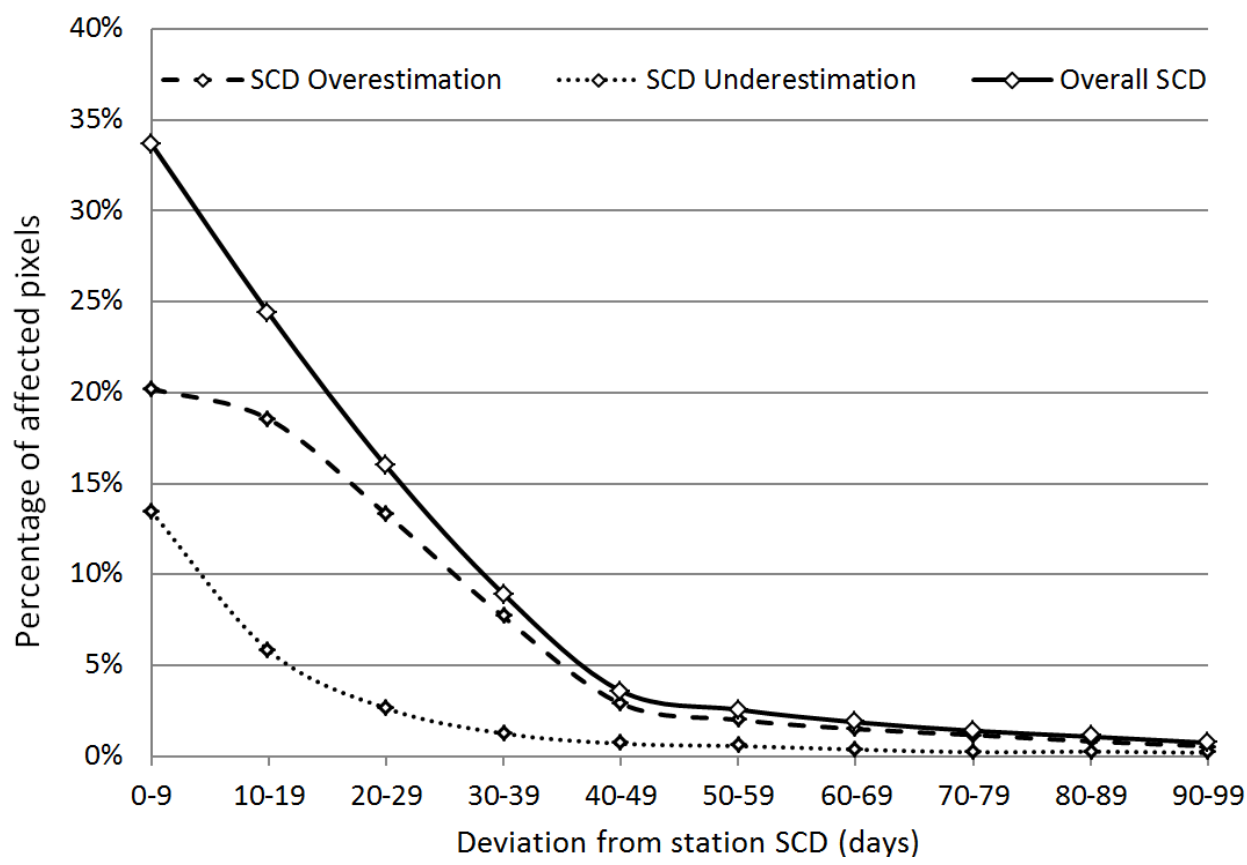

Figure 5. Accuracy of snow cover start and snow cover melt according to the comparison with station data

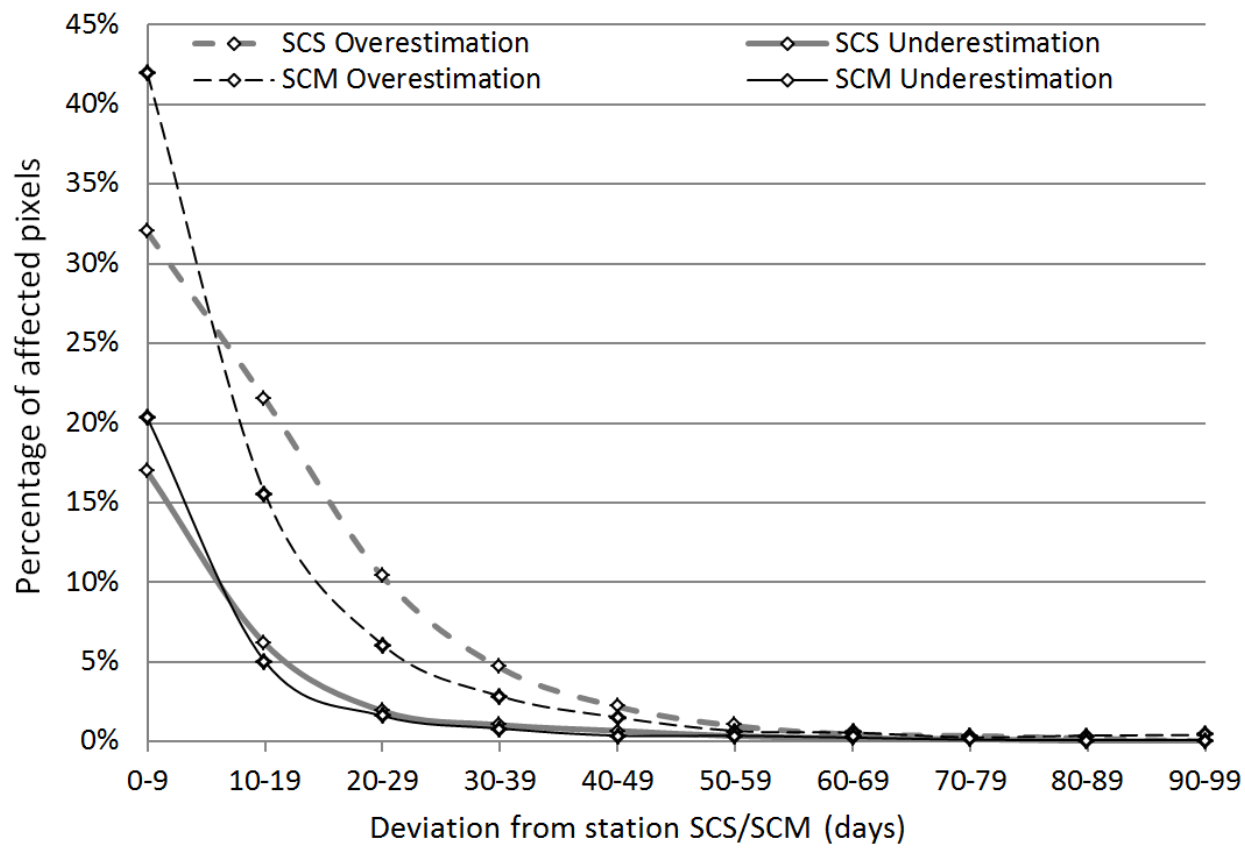

Overestimation of actual SCD is a more common problem than underestimation. Erroneous pixels are distributed more or less equally over the entire test area as can be discovered in Figures 6 and 7. Largest deviations are located in more northern latitudes while statistical spread is also wider in this region. 
Figure 6. Snow cover duration differences between MODIS and station data along a latitudinal axis.

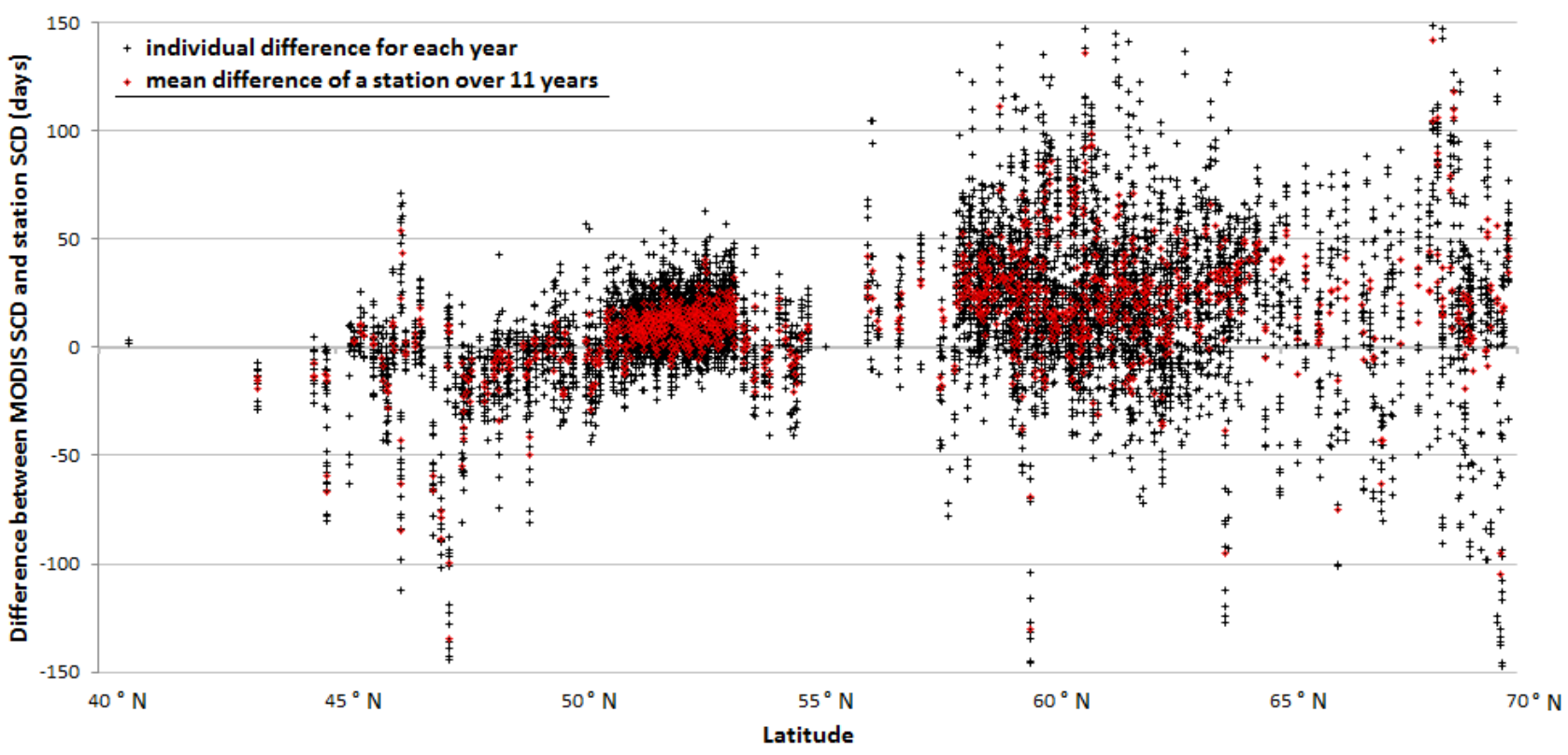

Figure 7. Snow cover duration differences between MODIS and station data along a longitudinal axis.

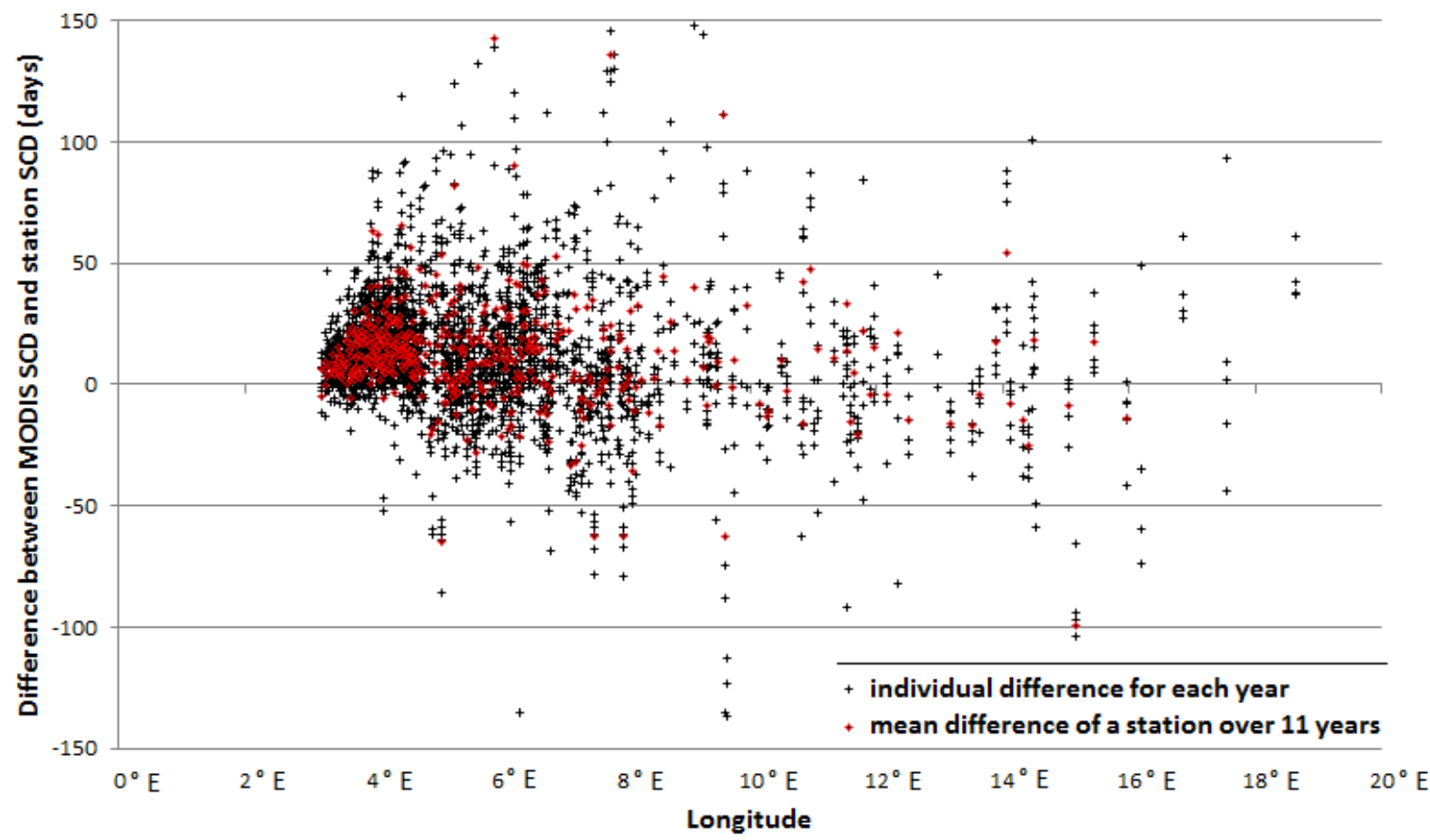

Possible reasons for the occurring errors are diverse: The presence of polar darkness is a major source for large divergences in northern latitudes. Pixel status is not updated during periods of darkness, leading to potentially higher error rates than in more southern latitudes. Few stations stick out due to extraordinary large differences between MODIS and station SCD. The locations of some of these stations lie within valleys of the Alps or the Scandinavian Mountains. This is, however, not true for all of the stations with continuously high error rates. We suppose that these stations are not suited for the comparison with our MODIS SCD product due to the surrounding terrain, vegetation cover, or urban environment. The accuracy of the original MOD10A1 and MYD10A1 data is lower for forested 
regions than it is, e.g., for agricultural areas. Pronounced topography also affects the accuracy [27]. Errors occurring in the original products will propagate through the whole time series and cause large divergences in regions with polar darkness or persistent cloud coverage. The uneven distribution of station locations is unfavorable. Unfortunately, no alternative ground truth time series was available to evaluate SCD, SCS, and SCM for Europe.

\subsection{SCD, SCS and SCM for Europe}

According to Equations (1)-(3), we processed the full time series of improved, cloud-free, daily snow cover data of whole Europe and derived SCD, SCS, and SCM for each hydrological year from $2000 / 2001$ to 2010/2011. The results of the single annual snow seasons are not included in this manuscript due to the large extent of these datasets. Figures 8, 9, and 10 depict the mean conditions of SCD, SCS, and SCM, respectively.

The mean SCD varies considerably within Europe, being greatest in Iceland and Norway. Portugal, Spain, and most parts of Italy and Greece usually stay snow-free. Mountainous regions like the Alps, the Carpathian Mountains in Romania, the Pyrenees at the border of France and Spain, and the Scandinavian Mountains stand out due to long SCD, early SCS, and late SCM. Valleys within these mountains are often characterized by much lower SCD than the surrounding ranges. Rain shadow affects these areas, preventing regular precipitation. Figure 11 includes a more detailed view on the Central European region to confirm this behavior.

The Aletsch Glacier, with $23 \mathrm{~km}$ the longest glacier of the Alps, is located in the largest area with perennial snow coverage. The MODIS-derived area with mean SCD of 365 days measures $87 \mathrm{~km}^{2}$ for this glacier massif, which is in good agreement with other sources $\left(81.7 \mathrm{~km}^{2}\right.$ in [49], $86.7 \mathrm{~km}^{2}$ in [50], $83 \mathrm{~km}^{2}$ in [51]). The analyses of the SCD-result showed that not only large glaciers such as Aletsch can be recognized. All glaciated areas larger than $\sim 10 \mathrm{~km}^{2}$ are clearly visible in the dataset, though of course for a detailed glacier inventory, high resolution remote sensing data is required as it was presented by [52] for the European Alps. The MODIS SCD dataset may, however, serve as an indicator for glaciated areas.

SCD is clearly associated with elevation (derived from SRTM-data [39]) in Figure 11. For Central Europe, mean SCD increases by 4 days per $100 \mathrm{~m}$ between 400 and $1,000 \mathrm{~m}$ elevation. This rate increases to 10 days per $100 \mathrm{~m}$ between 1,000 and 3,000 m elevation. Figure 12 shows the dependence between mean SCD and elevation for both, Central Europe and Scandinavia, where the rates of increasing SCD are similar but total values differ considerably. In Finland, Norway, and Sweden, mean SCD is generally around 150 days longer than in Central Europe. In Eastern Europe including the western part of Russia, SCD declines continuously with decreasing latitude. Figure 8 illustrates this fact with mean SCD of $\sim 200$ days at $65^{\circ} \mathrm{N}$, continuously decreasing by $\sim 8$ days per $1^{\circ}$ latitude while moving from Russia through Belarus, Ukraine, Romania, and finally reaching southern Bulgaria, where mean SCD is 20 days. Such latitudinal dependence of SCD is only observed for the most eastern part of the study area where climate is becoming more continental. 
Figure 8. Mean Snow Cover Duration from 2000 to 2011 for Europe.

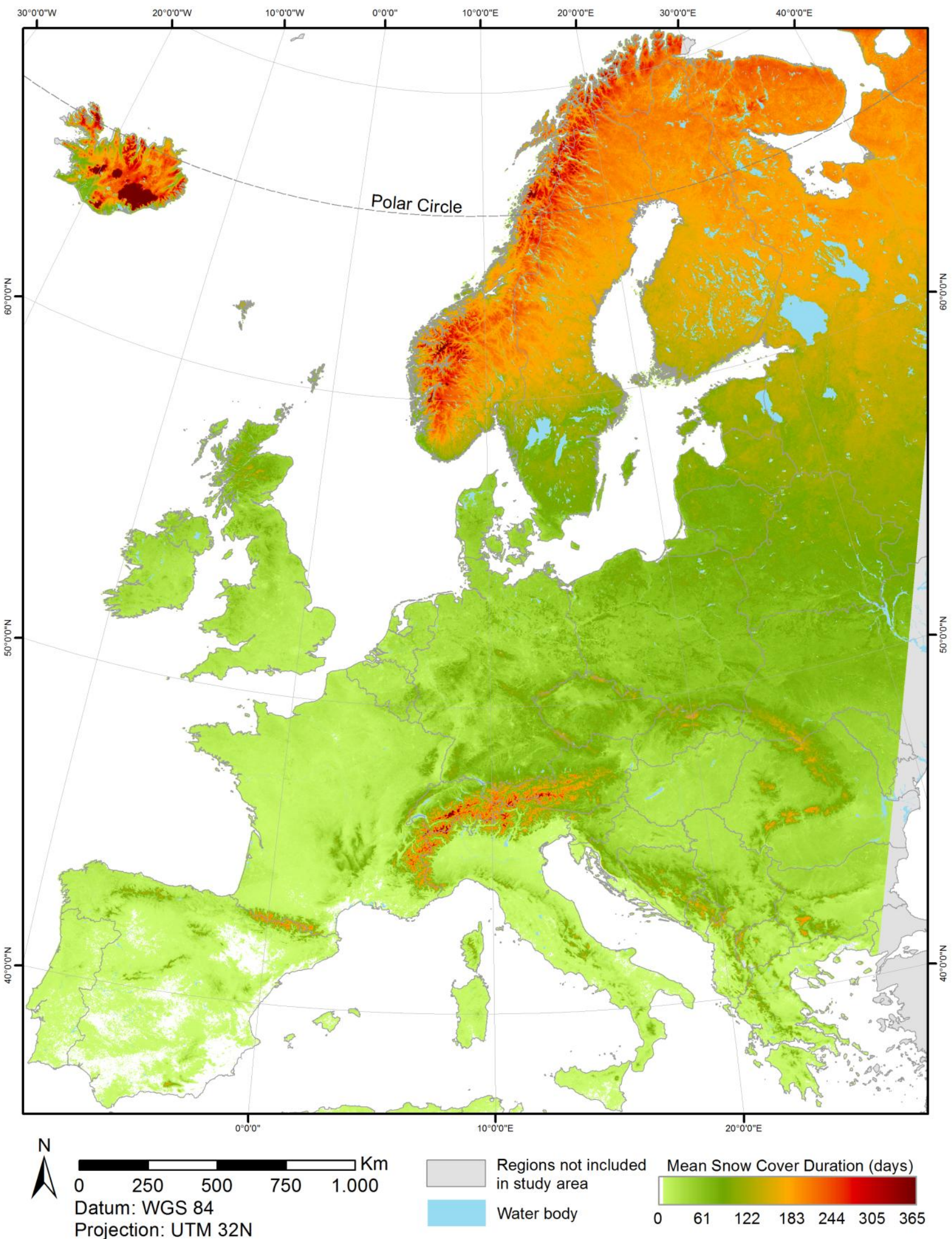


Figure 9. Mean Snow Cover Start from 2000 to 2011 for Europe.

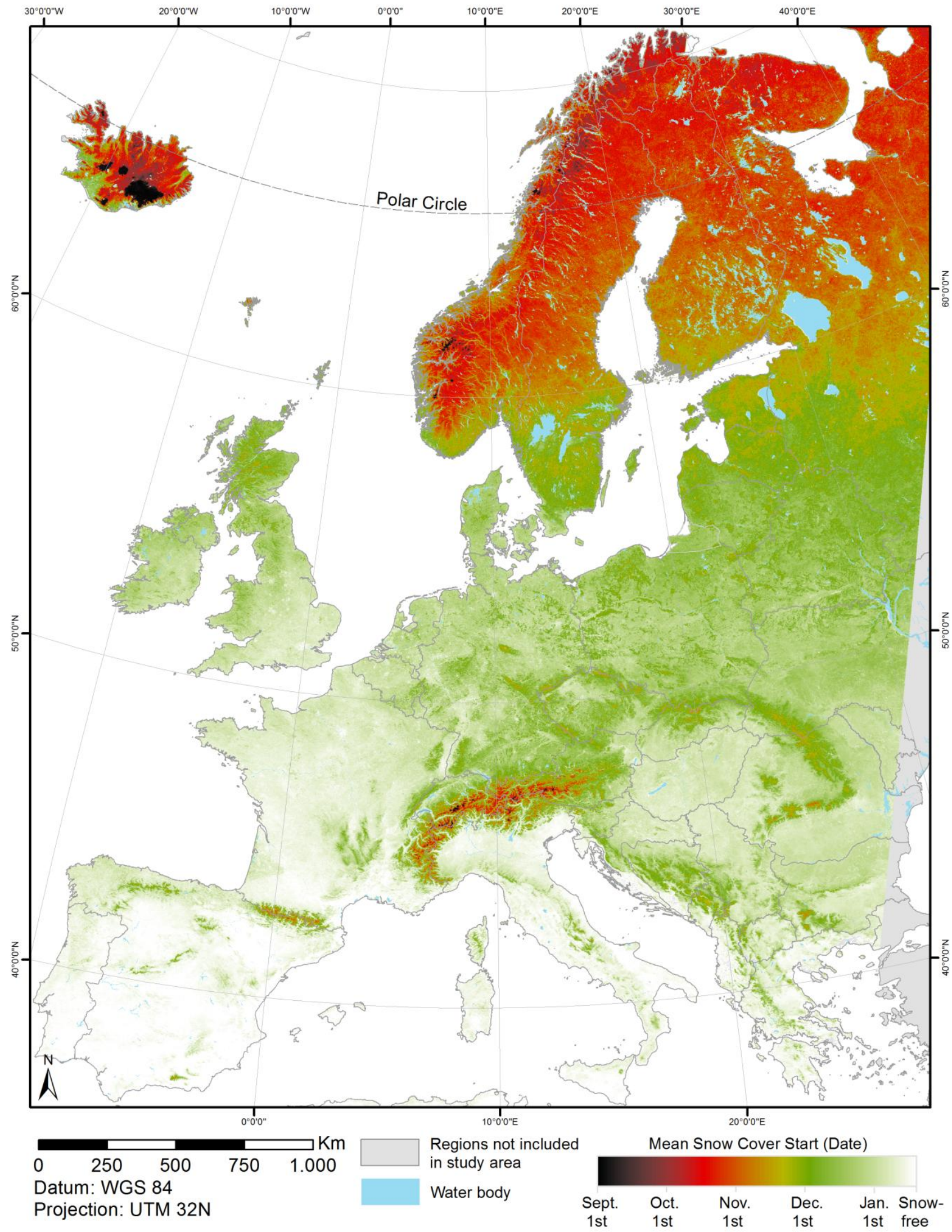


Figure 10. Mean Snow Cover Melt from 2000 to 2011 for Europe.

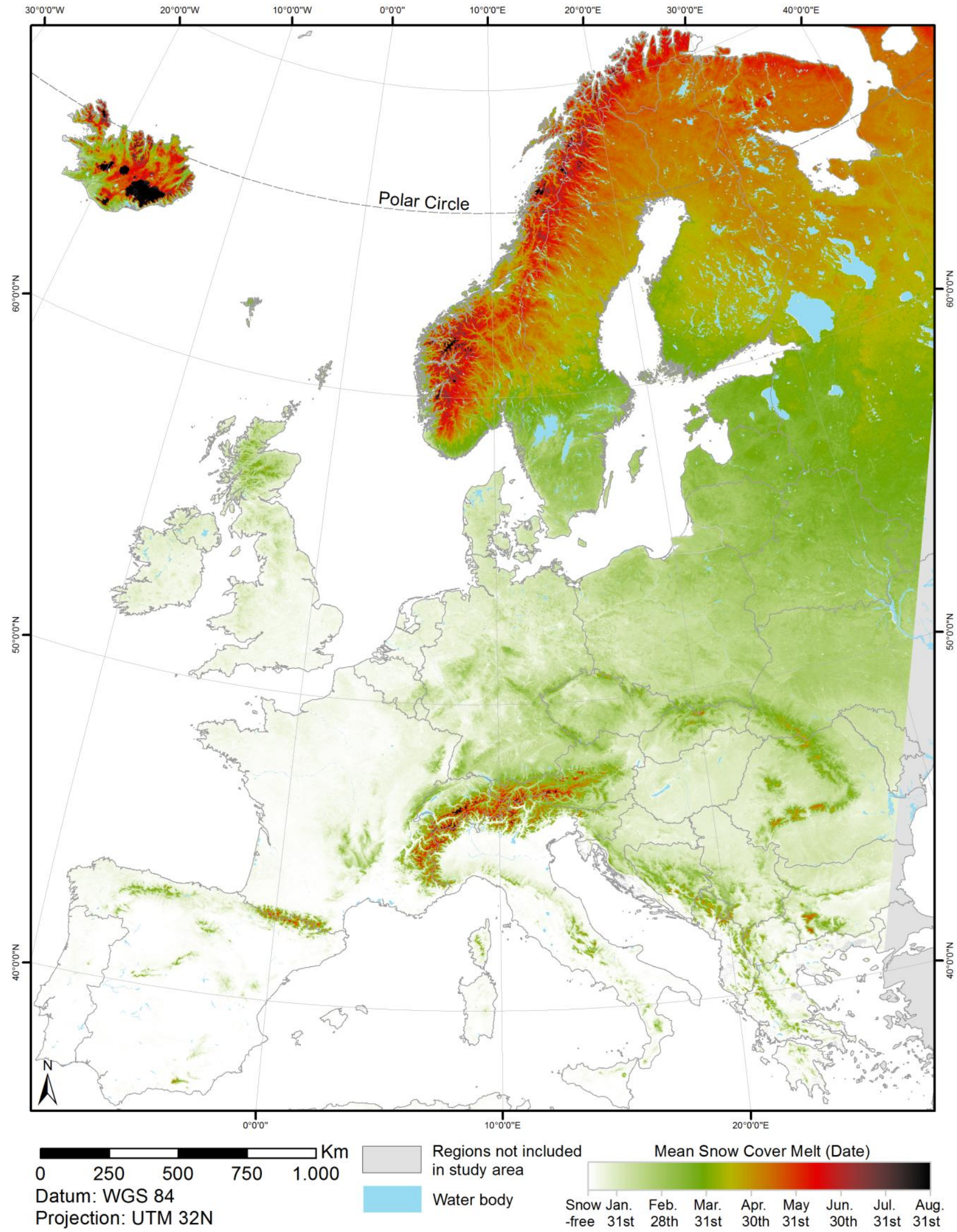


Figure 11. Mean Snow Cover Duration for Central European Alps.

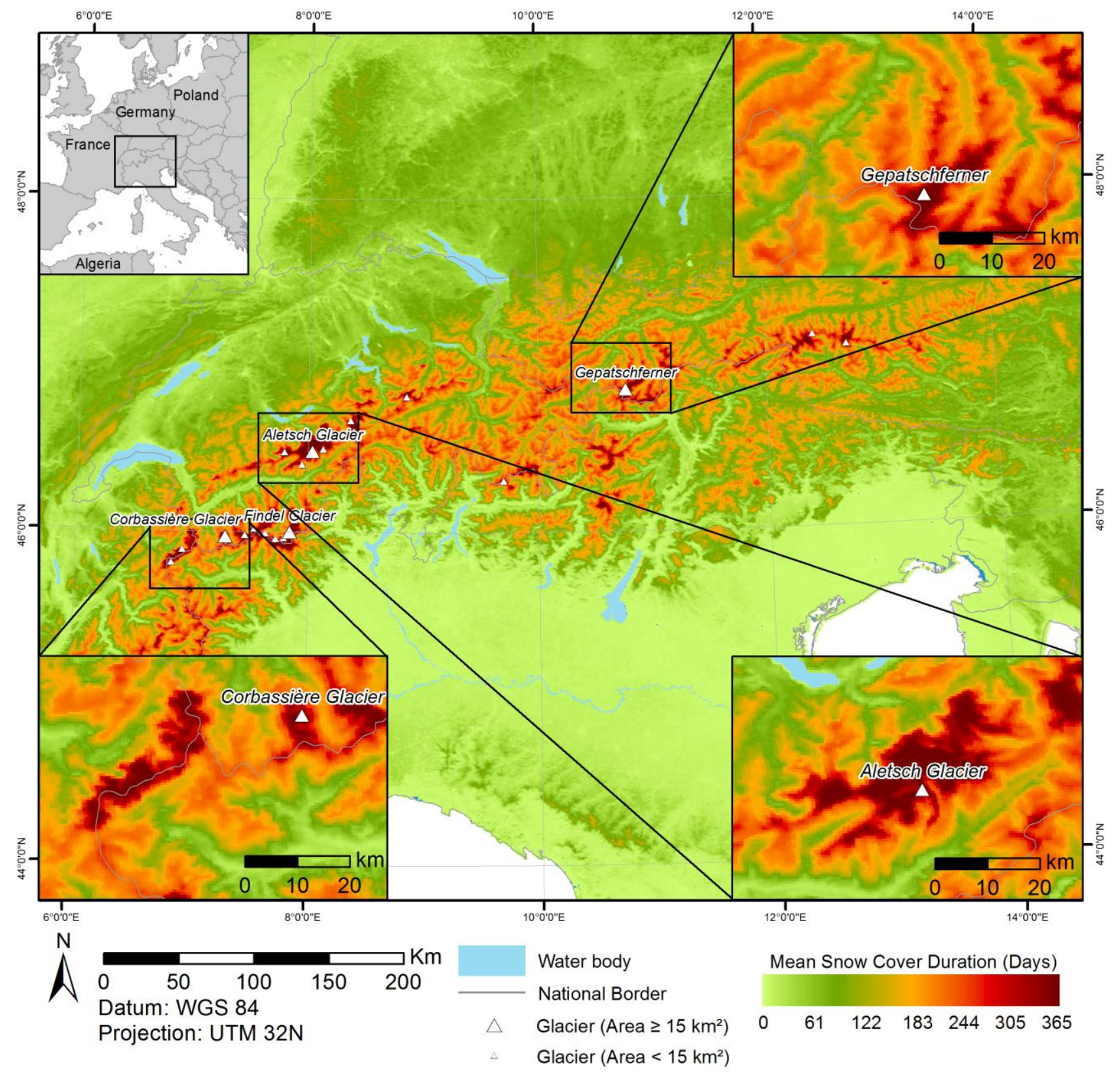

A further application field where the results of SCD, SCS and SCM can be applied is the analyses of abnormal events. A comparison of single snow cover seasons with the mean conditions (Figures 8-10) allows for a distinct identification of abnormal events. Though it is not possible to show the entire dataset range for all years here we included one year as an example: The hydrological year 2005/2006 stood out due to an extraordinary long SCD in large parts of Central Europe. The long SCD was caused by an exceptionally cold winter. A long, uninterrupted period with temperatures below freezing point affected Germany, Austria, and the Czech Republic [53]. Snow melt between late February and early April led to floods of Danube and Elbe Rivers. In Bad Reichenhall, Germany, 15 people were killed by a collapsing roof due to heavy snow [54]. Though the presented results include no information about snow mass or snow water equivalent (SWE), the extensive SCD can be recognized when comparing 2005/2006 SCD with mean SCD (Figure 13). 
Figure 12. Mean and 2005/2006 snow cover duration for Central Europe and Scandinavia, according to elevation zones of $100 \mathrm{~m}$.

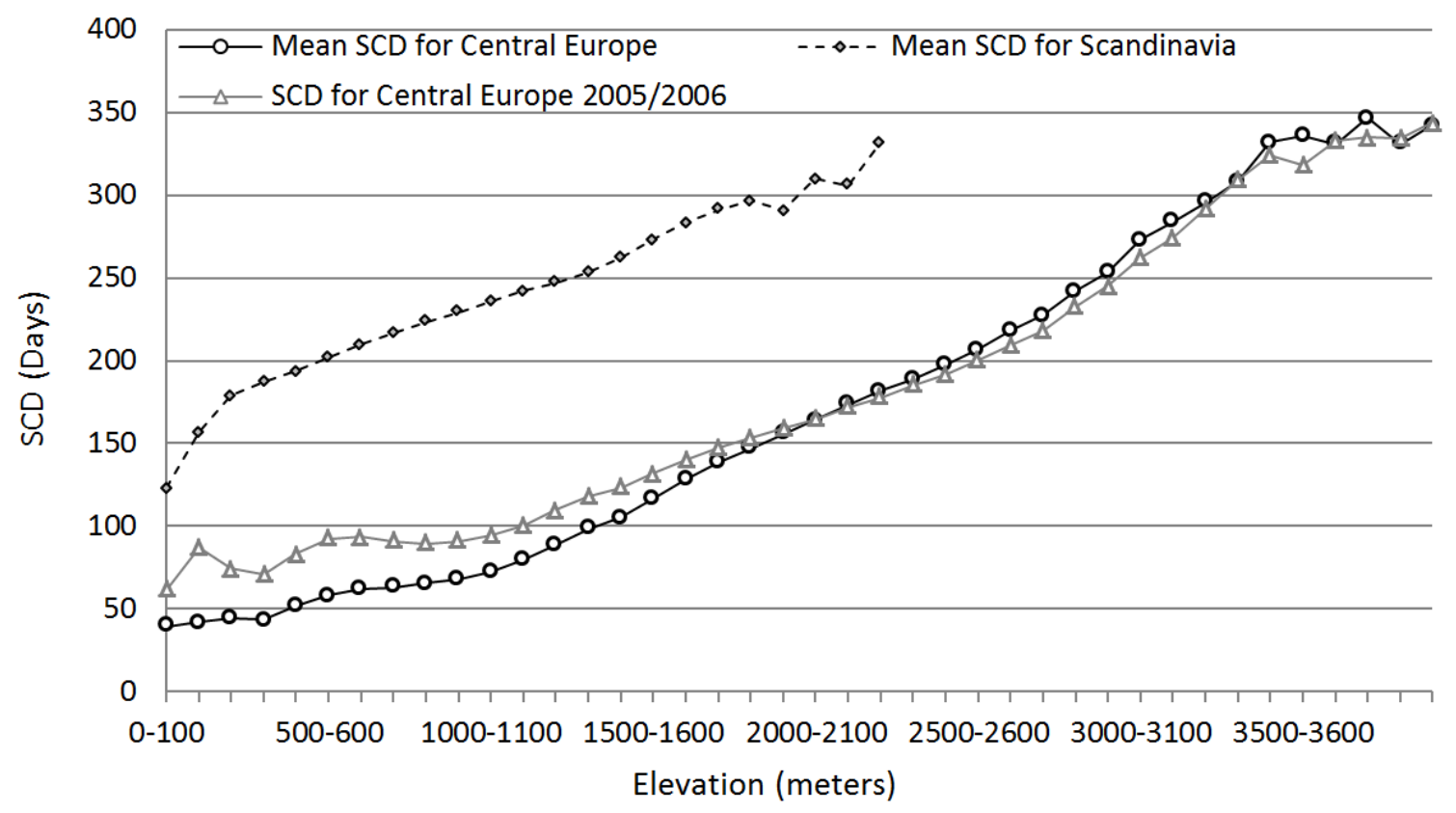

SCD was up to 80 days longer than under mean conditions for large regions of Czech Republic, Austria, and Germany. Considering the mean SCD of only 40 to 80 days these deviations are in fact remarkable. The deviations of SCS and SCM from mean conditions were also calculated as can be seen in Figure 14.

The results of Figure 14 show that although SCS occurred earlier for up to 20 days in eastern Austria, Southeast Germany, Czech Republic, and parts of Poland and Slovakia, the major deviations are observed in the SCM-result. This corresponds with the descriptions of [53] and [54]. Positive values in Figure 14(a)) refer to earlier SCS, negative values to later SCS. The contrary is true for Figure 14(b)) with positive values indicating later SCM (longer SCD) and negative values referring to earlier SCM. The 2005/2006 SCD plot in Figure 12 confirms that the divergences were greatest for elevation zones below $1,500 \mathrm{~m}$. It is important to identify not only SCD but also SCS and SCM since the latter two parameters may influence runoff water amounts due to melting snow considerably.

Another example presented in Figure 15 is the eruption of the Eyjafjallajökull Volcano in Iceland during March and April of 2010 (Figure 15(b,d)). SCD around the vent was up to 100 days lower than under normal conditions in the season 2009/2010. Adjacent glaciers, e.g. Mýrdalsjökull or Eyjafjallajökull, were also affected by lower SCD in this season. The same was observed when Grimsvötn Volcano erupted in late May 2011 in Iceland (Figure 15(c,e)). SCD decreased by up to 80 days for more than $330 \mathrm{~km}^{2}$ around the vent. This deviation was solely caused by earlier SCM which coincided with the volcanic eruption. It is, however, most likely that the deviations in SCD are caused by layers of volcanic ash covering the snow surface, therefore escaping the Snowmap algorithm due to changed spectral characteristics. The fact that the eruption of Grimsvötn was rich in the amount of incoming ash supports this assumption [55]. The trajectories of ash plumes originating from the 2010 eruption of Eyjafjallajökull pointed towards the British Islands, Scandinavia and Central Europe [56]. The prevailing wind directions allowed sedimentation only in southern Iceland [57]. The pattern of decreased SCD for the 2009/2010 season fits to this scenario (Figure 15(b,d)) since the decreased 
albedo of the ash-covered snow-surfaces may have caused the melting process to accelerate, leading to earlier SCM and shorter SCD [58].

Figure 13. Deviation of Snow Cover Duration in 2005/2006 compared to Mean Snow Cover Duration.

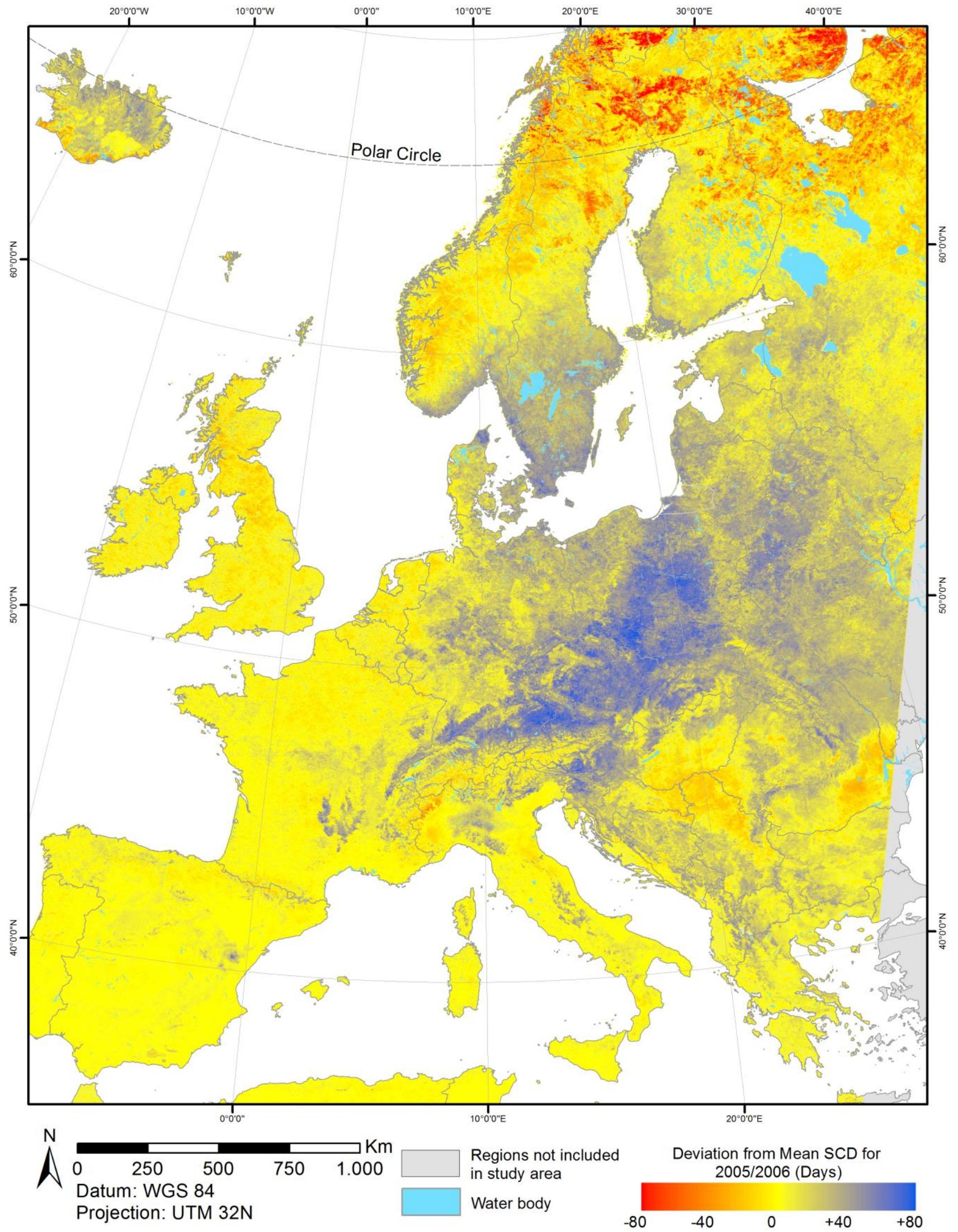


Figure 14. Deviation of 2005/2006 snow cover start (a) and snow cover melt (b) from mean conditions.
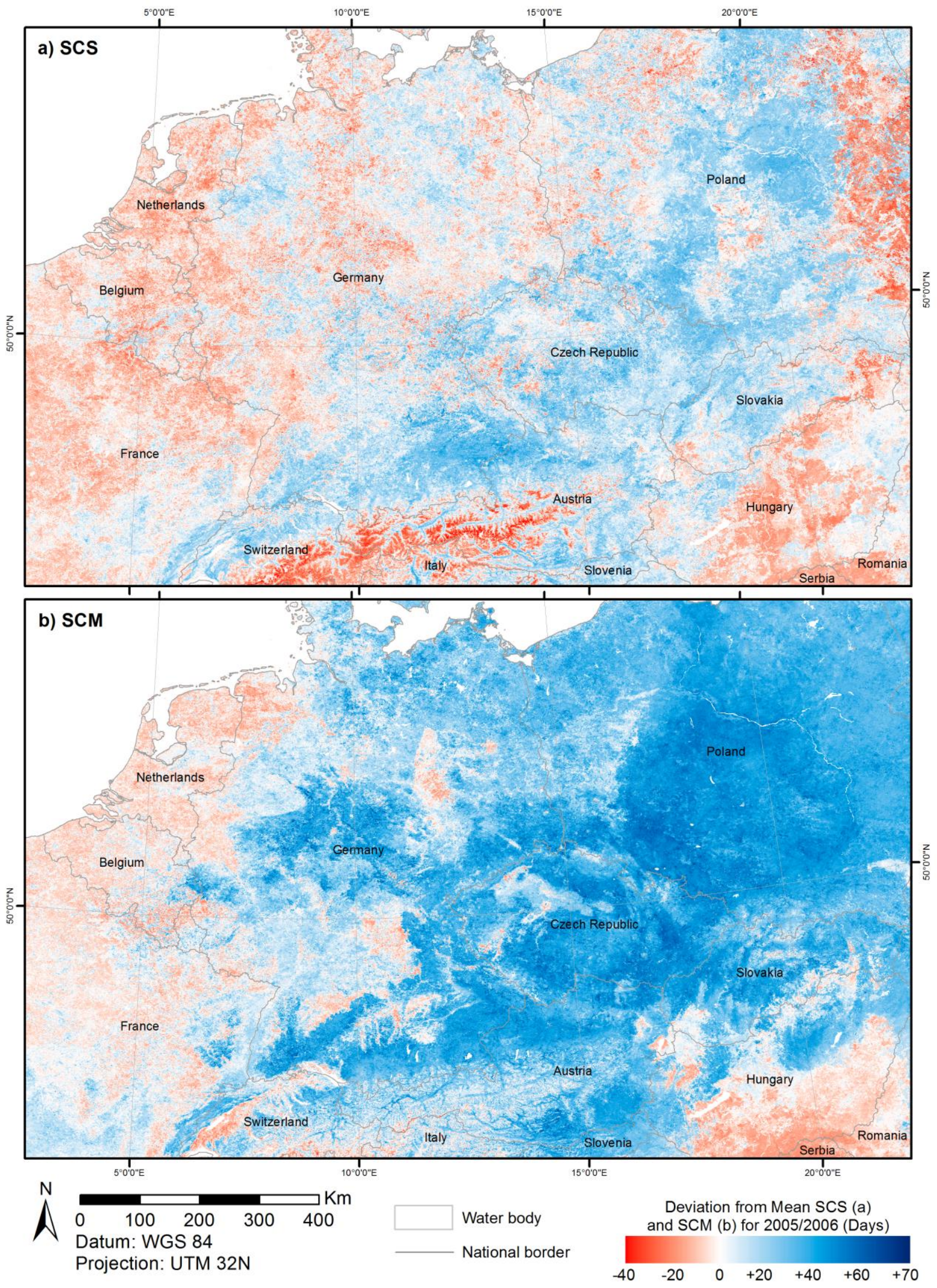
Figure 15. (a) Mean snow cover duration for Iceland. (b) Impact of the volcanic Eruption of Eyjafjallajökull on the snow cover duration. (c) Impact of volcanic eruption of Grimsvötn on the snow cover duration. (d) and (e) Details from (b) and (c).
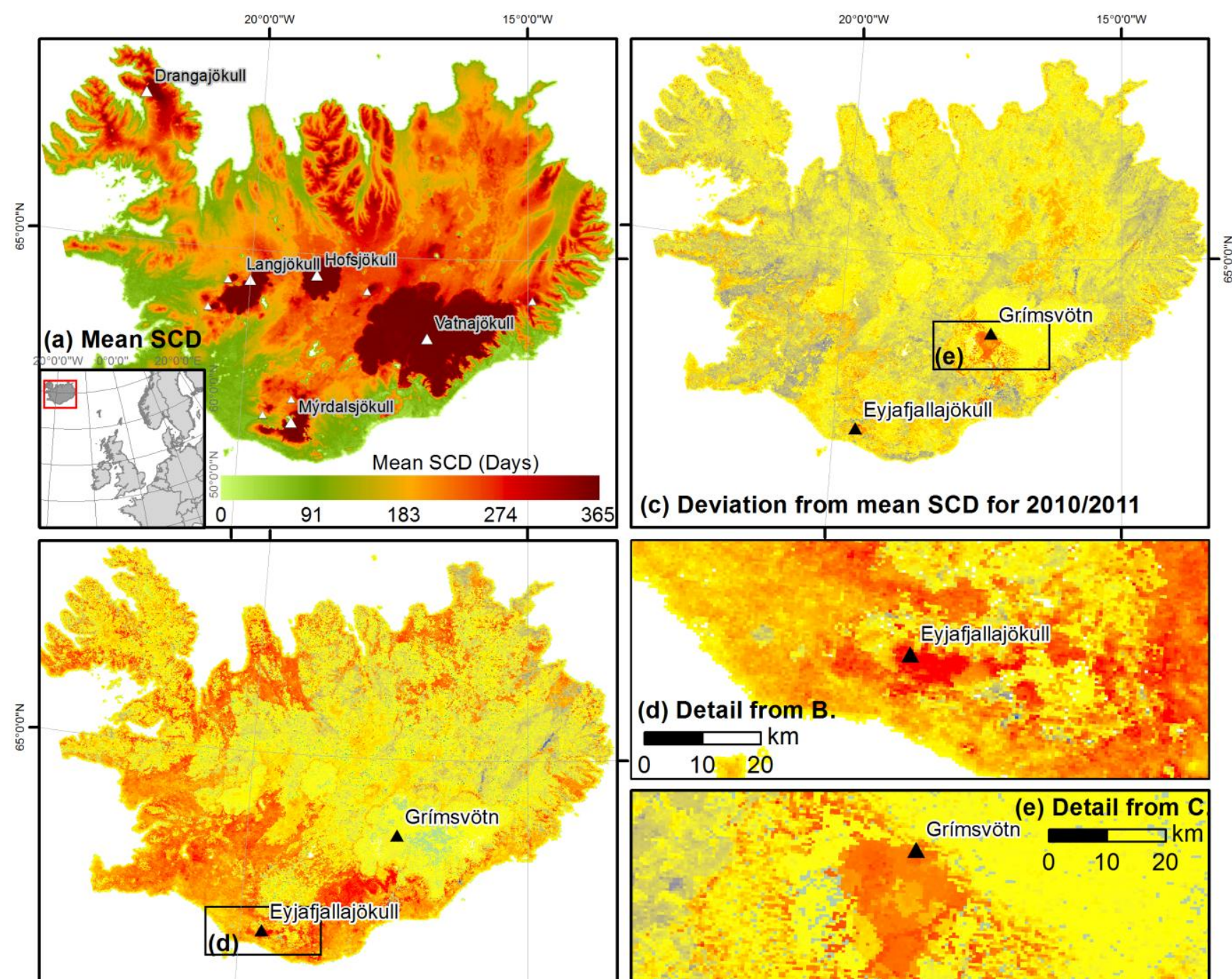

(b) Deviation from mean SCD for $2009 / 2010$
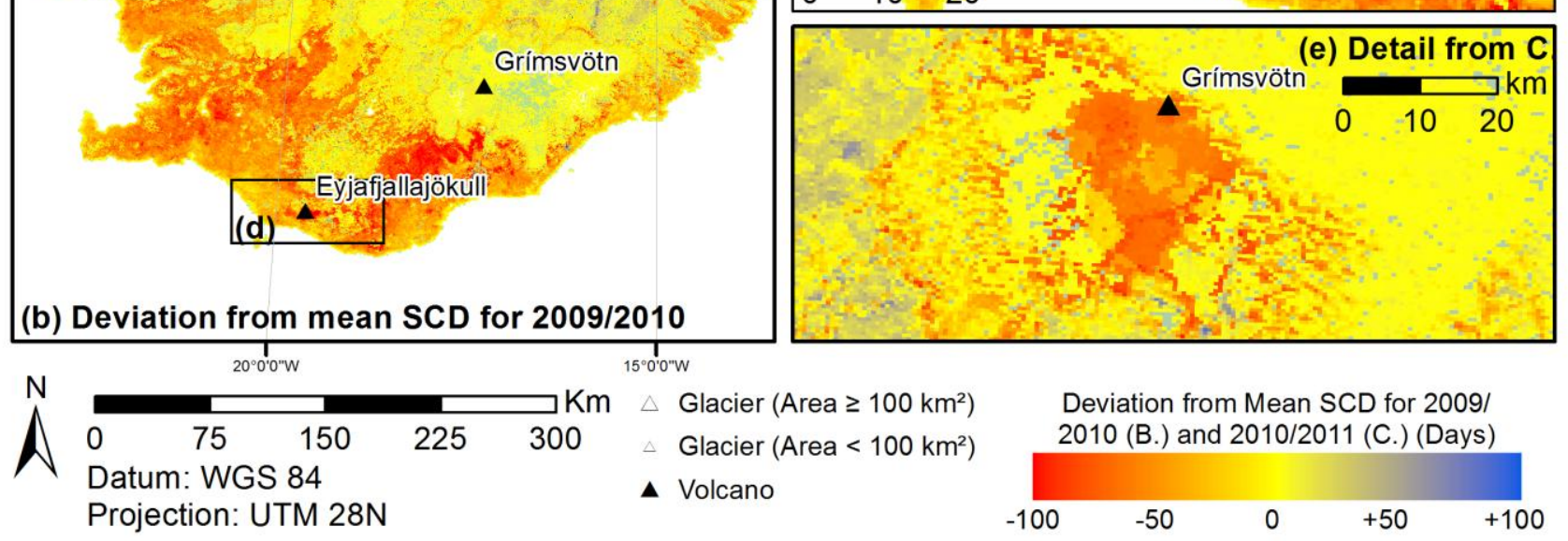

\section{Conclusions}

The presented snow cover inventory for Europe includes mean snow cover duration, snow cover start, and snow cover melt for the period from 2000 to 2011. The results are unique with respect to the spatial (500 $\mathrm{m}$ resolution for an area of 6.3 million $\mathrm{km}^{2}$ ) and temporal scale of the incorporated data (daily data for eleven hydrological years). The accuracy of the obtained results was assessed using data from meteorological stations. Eighty six percent of the area is characterized by deviations of less than 36 days between station data and MODIS derived snow cover products. Over-estimation of snow cover 
duration, snow cover start and snow cover melt was the predominant error in this study. Errors are larger in northern latitudes which may be caused by the presence of polar darkness in these regions.

The figures included in this study depict the mean snow cover conditions for the entire continent of Europe. The analysis of these results revealed both a latitudinal dependence of snow cover duration, snow cover start and snow cover melt for the most Eastern part of the area, as well as a strong influence of elevation on these parameters for Central Europe and Scandinavia. Glaciated areas with extents greater than $10 \mathrm{~km}^{2}$ are indicated in the snow cover duration result as areas with 365 snow covered days, though only high resolution remote sensing data can exclude all doubt about the precise glacier extent.

When comparing the mean conditions with single snow cover seasons, abnormal events can be identified. This was demonstrated for the season 2005/2006, where large parts of Central Europe experienced an extraordinarily long and cold winter. The comparison between mean snow cover duration, snow cover start, and snow cover melt with the respective results from 2005/2006 revealed a clearly increased snow cover duration and much later snow cover melt for the affected region. Concerning the volcanic eruptions in Iceland in 2010 (Eyjafjallajökull) and 2011 (Grimsvötn), snow cover duration was decreased considerably for the areas around the volcanic vents which is most likely the result of both volcanic ash covering the snow surface, and increased snow melt induced by the consequential higher absorption of solar radiation in the ash-covered region.

The results presented in this study may help to identify most endangered regions, quantify the possible effects of abnormal weather conditions and predict future scenarios. Advanced Very High Resolution Radiometer (AVHRR) data could be used to extend the time series back to 1980 and analyze Europe with respect to impacts of climate change on mean snow cover conditions.

\section{Acknowledgments}

We acknowledge the data providers in the ECA\&D project (Data and metadata available at http://eca.knmi.nl), NSIDC for providing MODIS snow cover data (nsidc.org/data/citations.html) and the Consortium for Spatial Information (http://srtm.csi.cgiar.org) for providing SRTM data.

We want to thank the four anonymous reviewers for their helpful comments and suggestions on the manuscript.

\section{References}

1. Zhang, Y.; Yan, S.; Lu, Y. Snow cover monitoring using MODIS data in Liaoning Province, Northeastern China. Remote Sens. 2010, 2, 777-793.

2. Klein, A.G.; Hall, D.K.; Nolin, A.W. Development of a Prototype Snow Albedo Algorithm for the NASA MODIS Instrument. In Proceedings of 57th Eastern Snow Conference, Syracuse, NY, USA, 17-19 May 2000; pp. 143-158.

3. Jain, S.K.; Goswami, A.; Saraf, A.K. Accuracy assessment of MODIS, NOAA and IRS data in snow cover mapping under Himalayan conditions. Int. J. Remote Sens. 2008, 29, 5863-5878.

4. Muntán, E.; Garcia, C.; Marti, G.; Gutiérrez, E. Reconstructing snow avalanches in the Southeastern Pyrenees. Nat. Hazard. Earth Sys. 2009, 9, 1599-1612. 
5. Zhao, Q.; Liu, Z.; Ye, B.; Wei, Z.; Fang, S. A snowmelt runoff forecasting model coupling WRF and DHSVM. Hydrol. Earth Syst. Sci. 2009, 13, 1897-1906.

6. Cherry, J.; Cullen, H.; Visbeck, M.; Small, A.; Uvo, C. Impacts of the North Atlantic Oscillation on Scandinavian hydropower production and energy markets. Water Resour. Manag. 2005, 19, 673-691.

7. Vikhamar, D.; Solberg, R. Snow-cover mapping in forests by constrained linear spectral unmixing of MODIS data. Remote Sens. Environ. 2003, 88, 309-323.

8. Beniston, M. Variations of snow depth and duration in the Swiss Alps over the last 50 years: Links to changes in large-scale climatic forcings. Climatic Change 1997, 36, 281-300.

9. Brown, R.D. Northern Hemisphere snow cover variability and change, 1915-97. J. Climate 2000, 13, 2339-2355.

10. Brodzik, M.J.; Armstrong, R.L.; Weatherhead, E.C.; Savoie, M.H.; Knowles, K.; Robinson, D. Regional trend analysis of satellite-derived snow extent and global temperature anomalies. Eos Trans. AGU 2006, 87, U33A-0011.

11. Foster, J.; Liston, G.; Koster, R.; Essery, R.; Behr, H.; Dumenil, L.; Verseghy, D.; Thompson, S.; Pollard, D.; Cohen, J. Snow cover and snow mass intercomparisons of general circulation models and remotely sensed datasets. J. Climate 1996, 9, 409-426.

12. Groisman, P.Y.; Knight, R.W.; Razuvaev, V.N.; Bulygina, O.N.; Karl, T.R. State of the ground: Climatology and changes during the past 69 years over Northern Eurasia for a rarely used measure of snow cover and frozen land. J. Climate 2006, 19, 4933-4955.

13. Lemke, P.; Ren, J.; Alley, R.; Allison, I.; Carrasco, J.; Flato, G.; Fujii, Y.; Kaser, G.; Mote, P.; Thomas, R.; Zhang, T. Chapter 4: Observations: Changes in Snow, Ice and Frozen Ground. In Climate Change 2007: The Physical Science Basis. Contribution of Working Group 1 to the Fourth Assessment Report of the Intergovernmental Panel on Climate Change; Solomon, S., Qin, D., Manning, M., Chen, Z., Marquis, M.C., Averyt, K., Tignor, M., Miller, H.L., Eds.; Intergovernmental Panel on Climate Change: Cambridge, UK and New York, NY, USA, 2007.

14. Barry, R.G.; Armstrong, R.; Callaghan, T.; Cherry, J.; Gearheard, S.; Nolin, A.; Russel, D.; Zaeckler, C. Snow. In Global Outlook for Ice and Snow; United Nations Environment Programme: Herfordshire, UK, 2007; pp. 39-62.

15. Jylhä, K.; Fronzek, S.; Tuomenvirta, H.; Carter, T. R.; Ruosteenoja, K. Changes in frost and snow in Europe and Baltic sea ice by the end of the 21st century. Climatic Change 2007, 86, 441-462.

16. Brown, R.; Mote, P. The response of Northern Hemisphere snow cover to a changing climate. $J$. Climate 2009, 22, 2124-2145.

17. Venäläinen, A. Estimation of road salt use based on winter air temperature. Meteorol. Appl. 2001, 8, 333-338.

18. Räisänen, J.; Eklund, J. 21st Century changes in snow climate in Northern Europe: A high-resolution view from ENSEMBLES regional climate models. Clim. Dyn. 2012, 38, 2575-2591.

19. Jasper, K.; Calanca, P.; Gyalistras, D.; Fuhrer, J. Differential impacts of climate change on the hydrology of two alpine river basins. Clim. Res. 2004, 26, 113-129.

20. Dietz, A.J.; Kuenzer, C.; Gessner, U.; Dech, S. Remote sensing of snow-A review of available methods. Int. J. Remote Sens. 2012, 33, 4094-4134. 
21. Groisman, P.Y.; Karl, T.R.; Knight, R.W. Changes of snow cover, temperature, and radiative heat balance over the Northern Hemisphere. J. Climate 1994, 7, 1633-1656.

22. Foppa, N.; Seiz, G. Inter-annual variations of snow days over Switzerland from 2000-2010 derived from MODIS satellite data. The Cryosphere 2012, 6, 331-342.

23. Falarz, M. Variability and trends in the duration and depth of snow cover in Poland in the 20th Century. Int. J. Climatol. 2004, 24, 1713-1727.

24. Schuler, D.V.; Beldring, S.; Forland, E.J.; Roald, L.A.; Skaugen, T.E. Snow Cover and Snow Water Equivalent in Norway: Current Conditions (1961-1990) and Scenarios for the Future (2071-2100); Met.No Report no. 01/2006; Norwegian Meteorological Institute: Oslo, Norway, 2006.

25. Systematic Observation Requirements for Satellite-Based Data Products for Climate. Supplemental Details to the Satellite-Based Component of the Implementation Plan for the Global Observing System for Climate in Support of the UNFCCC-2011 Update; WMO GCOS-154; WMO GCOS: Geneva, Switzerland, 2011; p. 127.

26. Hall, D.K.; Riggs, G.A.; Salomonson, V.V. Development of methods for mapping global snow cover using moderate resolution imaging spectroradiometer data. Remote Sens. Environ. 1995, 54, 127-140.

27. Hall, D.K.; Riggs, G.A. Accuracy assessment of the MODIS snow products. Hydrol. Process. 2007, 21, 1534-1547.

28. Klein, A.; Barnett, A.C. Validation of daily MODIS snow cover maps of the Upper Rio Grande River Basin for the 2000-2001 snow year. Remote Sens. Environ. 2003, 86, 162-176.

29. Maurer, E.P.; Rhoads, J.D.; Dubayah, R.O.; Lettenmaier, D.P. Evaluation of the snow-covered area data product from MODIS. Hydrol. Process. 2003, 17, 59-71.

30. Parajka, J.; Blöschl, G. Validation of MODIS snow cover images over Austria. Hydrol. Earth Syst. Sci. 2006, 10, 679-689.

31. Sorman, A.Ü.; Akyürek, Z.; Sensoy, A.; Sorman, A.A.; Tekeli, A.E. Commentary on comparison of MODIS snow cover albedo products with ground observations over the mountainous terrain in Turkey. Hydrol. Earth Syst. Sci. 2007, 11, 1353-1360.

32. Huang, X.; Liang, T.; Zhang, X.; Guo, Z. Validation of MODIS snow cover products using Landsat and ground measurements during the 2001-2005 snow seasons over Northern Xinjiang, China. Int. J. Remote Sens. 2011, 32, 133-152.

33. Simic, A.; Fernandes, R.; Brown, R.; Romanov, P.; Park, W. Validation of VEGETATION, MODIS, and GOES + SSM/I snow-cover products over Canada based on surface snow depth observations. Hydrol. Process. 2004, 18, 1089-1104.

34. Crane, R.G.; Anderson, M.R. Satellite discrimination of snow/cloud surfaces. Int. J. Remote Sens. 1984, 5, 213-223.

35. Riggs, G.A.; Hall, D.K. Snow Mapping with the MODIS Aqua Instrument. In Proceedings of 61st Eastern Snow Conference, Portland, OR, USA, 9-11 May 2004.

36. Hall, D.K.; Riggs, G.A.; Salomonson, V.V. MODIS/Terra Snow Cover Daily L3 Global 500m Grid V005, September 2000 to August 2011; National Snow and Ice Data Center: Boulder, CO, USA, 2000; Digital media. 
37. Hall, D.K.; Riggs, G.A.; Salomonson, V.V. MODIS/Aqua Snow Cover Daily L3 Global 500m Grid V005, July 2002 to August 2011; National Snow and Ice Data Center: Boulder, CO, USA, 2003; Digital media.

38. Metadata and Service Discovery Tool Reverb. Available online: http://reverb.echo.nasa.gov/reverb (accessed on 2 June 2012).

39. Jarvis, A.; Reuter, H.I.; Nelson, A.; Guevara, E. CGIAR-CSI SRTM 90m Database; Hole-filled SRTM for the globe Version 4; 2008. Available online: http://srtm.csi.cgiar.org (accessed on 31 July 2012).

40. European Climate Assessment \& Dataset ECA\&D. Available online: http://eca.knmi.nl (accessed on 14 June 2012).

41. Klein Tank, A.M.G.; Wijngaard, J.B.; Können, G.P.; Böhm, R.; Demarée, G.; Gocheva, A.; Mileta, M.; Pashiardis, S.; Hejkrlik, L.; Kern-Hansen, C.; Heino, R.; Bessemoulin, P.; et al. Daily dataset of 20th-Century surface air temperature and precipitation series for the European climate assessment. Int. J. Climatol. 2002, 22, 1441-1453.

42. Kottek, P.; Grieser, J.; Beck, C.; Rudolf, B.; Rubel, F. World map of the Köppen-Geiger climate classification updated. Meteorol. Z. 2006, 15, 259-263.

43. Parajka, J.; Blöschl, G. Spatio-temporal combination of MODIS images-Potential for snow cover mapping. Water Resour. Res. 2008, 44, 1-13.

44. Wang, X.; Xie, H. New methods for studying the spatiotemporal variation of snow cover based on combination products of MODIS Terra and Aqua. J. Hydrol. 2009, 371, 192-200.

45. Wang, X.; Xie, H.; Liang, T. Development and assessment of combined Terra and Aqua MODIS snow cover products in Colorado Plateau, USA and Northern Xinjiang, China. J. Appl. Remote Sens. 2009, 3, 1-15.

46. Khalsa, S.J.S.; Aizen, V.B. Variability in Central Asian seasonal snow cover during the MODIS period of record. In Proceedings of 2008 IEEE International Geoscience \& Remote Sensing Symposium, Boston, MA, USA, 6-11 July 2008; Volume 10, pp. 1-2.

47. Gafurov, A.; Bárdossy, A. Cloud removal methodology from MODIS snow cover product. Hydrol. Earth Syst. Sci. 2009, 13, 1361-1373.

48. Hall, D.K.; Riggs, G.A.; Salomonson, V.V.; Digirolamo, N.E.; Bayr, K.J. MODIS snow-cover products. Remote Sens. Environ. 2002, 83, 181-194.

49. Holzhauser, H.; Magny, M.; Zumbühl, H.J. Glacier and lake-level variations in west-central Europe over the last 3500 years. The Holocene 2005, 15, 789-801.

50. Kelly, M.A.; Kubik, P.W.; Von Blanckenburg, F.; Schlüchter, C. Surface exposure dating of the Great Aletsch Glacier Egesen moraine system, western Swiss Alps, using the cosmogenic nuclide ${ }^{10}$ Be. J. Quaternary Sci. 2004, 19, 431-441.

51. World Glacier Monitoring Service (WGMS). Fluctuations of Glaciers 2000-2005; Haeberli, W., Zemp, M., Hoelzle, M. Eds.; ICSU(FAGS)/IUGG(IACS)/UNEP/UNESCO/WMO, World Glacier Monitoring Service, University of Zurich: Zunich, Switzerland, 2008; Volume IX.

52. Paul, F.; Frey, H.; Le Bris, R. A new glacier inventory for the European Alps from Landsat TM scenes of 2003: challenges and results. Ann. Glaciol. 2011, 52, 144-152.

53. Croci-Maspoli, M.; Davies, H.C. Key Dynamical features of the 2005/2006 European winter. Mon. Weather Rev. 2008, 137, 664-678. 
54. Pinto, J.G.; Brücher, T.; Fink, A.H.; Krüger, A. Extraordinary snow accumulations over parts of central Europe during the winter of 2005/06 and weather-related hazards. Weather 2007, 62, 16-21.

55. ESA News: Satellites Monitor Icelandic Ash Plume. Available online: http://www.esa.int/ esaCP/SEM3WUMSNNG_index_0.html (accessed on 11 June 2012).

56. Flentje, H.; Claude, H.; Elste, T.; Gilge, S.; Köhler, U.; Pass-Dülmer, C.; Steinbrecht, W.; Thomas, W.; Werner, A.; Fricke, W. The Eyjafjallajökull eruption in April 2010-Detection of volcanic plume using in situ measurements, ozone sondes and lidar-ceilometer profiles. Atmos. Chem. Phys. 2010, 10, 10085-10092.

57. Bartnicki, J.; Hov, O.; Valdebenito, A.; Gauss, M. Eyjafjallajökull eruption-Calculating the movement of ash. Meta 2010, 2, 4-10.

58. Gerland, S.; Aars, J.; Bracegirdle, T.; Carmack, E.; Hop, H.; Hovelsrud, G.K.; Kovacs, K.; Lydersen, C.; et al. Ice in the Sea. In Global Outlook for Ice and Snow; United Nations Environment Programme: Herfordshire, UK, 2007; pp. 39-62.

(C) 2012 by the authors; licensee MDPI, Basel, Switzerland. This article is an open access article distributed under the terms and conditions of the Creative Commons Attribution license (http://creativecommons.org/licenses/by/3.0/). 